\title{
Labyrinthine Growth Pattern
}

National Cancer Institute

\section{Source}

National Cancer Institute. Labyrinthine Growth Pattern. NCI Thesaurus. Code C159155.

A morphologic finding where cells are arranged in the form of a maze. 